УДК 37.013 .73

https://doi.org/10.33989/2075-1443.2020.43.212702

orcid.org/ 0000-0003-1862-3639

\title{
Алла Ільченко
}

ІЛЬЧЕНКО Алла Михайлівна - кандидат педагогічних наук, дочент кафедри гуманітарних і сочіальних дисчиплін Полтавської держсавної аграрної академії. Сфера наукових інтересів - історія світової педагогіки, актуальні питання сучасної філософії освіти.

\section{ФІЛОСОФСЬКІ ЗАСАДИ СТАНОВЛЕННЯ ТА РОЗВИТКУ ГУМАНІСТИЧНОЇ ПАРАДИГМИ ОСВІТИ}

У статті проаналізовано філософські засади становлення та розвитку гуманістичної педагогіки. Визначено поняття гуманізму як системи світоглядних орієнтацій, иентром якої постає особистість людини, ї̈ самість, високе призначення та право на вільну самореалізацію. Зазначається, щуо гуманістична інтерпретаиія иілей освіти полягає у тому, щзоб зробити повноцінним і гідним життя людини в сучасному суспільстві. Пояснюється, що принцип гуманізму в педагогіщі трунтується на положенні про безмежну віру у природу кожної дитини, ї̈ цінність у иьому світі, орієнтації на ідеал вільної, самостійної, активноі особистості.

Висвітлені погляди на природу ц̌ процеси розвитку особистості дитини відомих філософів-просвітителів, педагогів: Джона Локка, Жан-Жака Руссо, Йогана Фрідріха Гербарта, Йогана Генріха Песталоичі, Фрідріха Фребеля, Марії Монтессорі. Показано вплив філософських ідей зарубіжних філософів-освітян на розвиток гуманістичної парадигми сучасної освіти.

Ключові слова: гуманізм, освіта, особистість, гуманістична парадигма, філософія освіти, просвітитель, педагог.

Постановка проблеми. Основним завданням національної концепції реформування сучасної системи освіти є іiі демократизація та гуманізація, що передбачають утвердження людини як найвищої соціальної цінності, розкриття іiї здібностей, можливостей та задоволення

(C) А. М. Ільченко, 2020 
різноманітних освітніх потреб. Відповідно, метою освітнього процесу $\epsilon$ підготовка гармонійно розвиненої особистості як свідомого, активного суб'єкта, здатного вирішувати будь-які проблемні питання, творити, змінювати, удосконалювати навколишній світ та самого себе. У зв'язку з цим в систему освіти впроваджується гуманістичний підхід, теоретичне осягнення якого передбачає осмислення світоглядно-філософських уявлень про природу й процеси розвитку вільної, креативної, самостійної, самодостатньої особистості. Дана проблема сприяла зародженню та становленню гуманістичної парадигми освіти. Вирішення цих питань потребує неупередженої, об'єктивної оцінки світоглядно-філософських і психолого-педагогічних надбань, поглядів, переконань щодо становлення і розвитку особистості, для подальшого використання цих ідей у навчально-виховному процесі.

Аналіз останніх досліджень і публікацій. Дослідження гуманізму та гуманістичних засад в філософії освіти проводяться як у вітчизняній, так і зарубіжній філософській, психолого-педагогічній, культурологічній, соціологічній науках. Значний внесок у розробку теорії гуманізму зробили М. Бердяєв, А. Горєлов, А. Кудішина, Л. Морозова, А Рибін та інші науковці. Філософські аспекти даної проблеми висвітлюють О. Горак, В. Гузенко, Н. Кіяшко, П. Кравченко, А. Круглова, К. Ламонта, Ю. Хоменко, інші. Питання гуманістичної освіти розглядають у своїх наукових працях В. Андрущенко, Н. Ашиток, І. Бех, О. Вовк, С. Гончаренко, І. Зязюн, А. Ільченко, С. Осипенко, В. Пазенок, О. Савченко, I. Якиманська. Проте, як засвідчує історія гуманізму, його актуальні питання будуть залишатися відкритими, допоки існує людство.

Мета статті: висвітлення, на основі аналізу наукової літератури 3 обраної проблеми, сутності змісту поняття «гуманізм» та аналіз світоглядно-філософських засад зарубіжної гуманістичної педагогіки.

Виклад основного матеріалу. Як зазначено у філософському енциклопедичному словнику, гуманізм - це система світоглядних орієнтацій, центром якої постає людина, її самість, високе призначення та право на вільну самореалізацію. У вузькому розумінні, гуманізм пояснюється як новий світогляд, що характеризується вірою в людину та iii можливості, у більш ширшому - реальність гетерогенного простору культури, що зумовлює формування концепцій загальнолюдських цінностей і цивілізаційних стандартів якості життя (Філософський енциклопедичний словник, 2002, с. 134-135). Гуманізм, зауважує О. Вершиніна, це філософський і етико-соціологічний принцип відношення до людини як до найвищої цінності, в основі якого лежать такі феномени: етична норма, соціальний ідеал, духовна цінність, свобода, взаємодопомога і співробітництво, повага до прав і гідності люди- 
ни, рівність і рівноправність, справедливість, захист від зла і насилля тощо (Вершинина, 2004, с. 9).

Гуманістична інтерпретація цілей освіти полягає у тому, щоб зробити повноцінним і гідним життя дитини в сучасному суспільстві. Принцип гуманізму в педагогіці грунтується на положенні про безмежну віру у природу кожного вихованця, його цінність у цьому світі, орієнтація на ідеал вільної, самостійної, активної особистості. Оптимальне поєднання наукової філософської і педагогічної спадщини 3 сучасними національними світоглядно-філософськими та педагогічними ідеями, використання кращих зразків зарубіжної філософії, психології, педагогіки сприятиме розв'язанню проблеми гуманізації сучасної освіти.

Аналіз наукової літератури показав, що на становлення та розвиток гуманістичної педагогіки вплинули погляди зарубіжних просвітителів, філософів, педагогів, зокрема: Джона Локка, Жан-Жака Руссо, Йогана Фрідріха Гербарта, Йогана Генріха Песталоцці, Фрідріха Фребеля, Марії Монтессорі.

Англійський педагог і філософ Джон Локк висвітлив свої світоглядні ідеї у працях: «Лист про віротерпимість», «Дослідження про людський розум», «Думки про виховання», «Розумність християнства», які були актуальними в минулому і можуть 3 успіхом використовуватися сучасними педагогами. Філософ пропагував і поширював знання про високі моральні принципи, ідеї добра та справедливості. Формування особистості джентльмена, міцного тілом і сильного духом, наділеного кращими якостями для майбутньої підприємницької і комерційної діяльності - основна мета навчання (Поздняков, 2009, с. 24). Джон Локк робить висновок про те, що процес формування особистості залежить від належного виховання. На думку філософа, всі люди, незалежно від соціального статусу, мають від природи однакові можливості для розвитку розуму та здібностей, а відмінності між ними є результатом різних умов життя й виховання. Особливу увагу він звертав на звільнення розуму вихованців від забобонів і упереджень, на розвиток самостійності суджень. Підкреслюючи значення у вихованні дітей прикладу дорослих, філософ-педагог надавав також особливого значення індивідуальному підходу та врахуванню вікових особливостей кожної дитини в процесі навчання. Джон Локк вважав за необхідне розвивати допитливість, інтерес до засвоєння знань, з дітьми молодшого віку рекомендував використовувати ігрові методи навчання, поєднувати розумову працю 3 трудовим навчанням (Локк, 1988, с. 410).

Проте, на наш погляд, педагогіці Джона Локка притаманні й суперечності. Всі його прогресивні думки стосувалися лише навчання 
і виховання дітей дворян та буржуазії. Призначення простого народу, на думку філософа, - фізична праця, що не потребує грунтовної підготовки й сприяє зміцненню здоров'я. Також, вимагаючи гуманного ставлення до дитини, він все ж таки допускав фізичні покарання, навіть жорстокість.

Французький просвітитель, філософ, письменник, педагог ЖанЖак Руссо вважав, що виховання моральних якостей у дітей має відбуватися в процесі здійснення «добрих справ» та ознайомлення з історією. У своїй педагогічній системі значне місце він надавав праці, яка $€$ засобом виховання й самоціллю. Виховання людини педагог поділив на чотири вікові періоди: 1) від народження до двох років (фізичне виховання); 2) від двох до дванадцяти років (період «сну розуму», розвиток органів чуття); 3) від дванадцяти до п'ятнадцяти років (розумове виховання); 4) від п'ятнадцяти до повноліття (період морального і статевого виховання) (Руссо, 2005).

Філософ-освітянин також обгрунтував теорію вільного виховання. У своїх поглядах він виходив із того, що вчитель не повинен нав'язувати своєї волі дитині. Його завдання полягає в тому, щоб сприяти природному росту дитини, створювати умови для їі розвитку, організовувати середовище, в якому дитина матиме самостійність і свободу. Педагог також повинен давати дитині такі знання, які відповідають ії інтересам та досвіду. На думку Жан-Жака Руссо, такий підхід до виховання й навчання розвиває відповідальність людини за свої справи, вчинки, вчить будувати свою поведінку так, аби жити вільно, у злагоді та гармонії 3 іншими людьми (Руссо, 2005). Ці ідеї вільного розвитку дитини підтримувалися й іншими педагогами й згодом реалізувалися в практиці.

Швейцарський педагог-гуманіст Йоган Генріх Песталоцці визначав основне завдання виховання - розвиток здібностей дитини відповідно до законів природи. Він вважав, що дитина народжується із задатками, з прагненням до діяльності, в процесі якої й розвиваються здібності. Педагог розробив теорію елементарної освіти, спрямовану на забезпечення гармонійного розвитку дитини, що охоплює розумове, морально-естетичне й фізичне виховання у тісному взаємозв'язку. У вихованні він радив починати з найпростіших елементів. Наприклад, у моральному вихованні таким найпростішим елементом, на його думку, $€$ любов дитини до матері, яку дитина природно й поступово спочатку переносить на інших членів своєї родини, потім - на навколишніх $\mathrm{i}$, нарешті, - на все людство. У розумовому вихованні основним завданням Йоган Генріх Песталоцці вважав засвоєння дитиною знань, що грунтуються на чуттєвому досвіді, розвиток розумових здібностей (Песталоцци,1981, с. 234). 
Йоган Генріх Песталоцці є одним із перших педагогів, які прагнули практично пов'язати навчання 3 продуктивною працею вихованців. Для підготовки дитини до трудової діяльності він намагався створити «елементарну гімнастику» - систему вправ, спрямовану на розвиток фізичних сил, набуття необхідних у житті трудових умінь. Для дітей, які в майбутньому працюватимуть на промисловості, він вважав за необхідне розробити, на основі «елементарної гімнастики», «індустріальну гімнастику», яка б складалася зі спеціальних вправ для рук і пальців, що допомагали б оволодіти різноманітними й, часом, складними трудовими прийомами (Ільченко, 2006). Педагогічні погляди Йогана Генріха Песталоцці, особливо ідея розвивального навчання, значною мірою вплинули на розвиток дидактики, приватних методик у багатьох країнах світу.

Німецький педагог, теоретик дошкільного виховання Фрідріх Фребель, виходячи із природних особливостей дітей молодшого віку, а саме: рухливість, безпосередність, допитливість, прагнення до наслідування, розробив власну систему гуманного дошкільного виховання, що поширилася згодом у різних країнах світу. Він поглиблював ідеї свободи розвитку, пізнання індивідуальності дитини, вважаючи, що виховання має бути пасивним і «обережним», а не спрямовуючим й активним. Для задоволення потреб дитини в діяльності й спілкуванні 3 іншими дітьми, зауважував Фрідріх Фребель, необхідно організовувати іiї заняття в колі ровесників, якому він і дав поетичну назву «дитячий садок». Основна мета дитячого садка: сприяти розвитку природних здібностей дитини. Педагог пропагував створення дитячих садків, розробивши своєрідну методику роботи вихователів, поклавши в іii основу розвиток органів чуття, рухів і мовлення шляхом ігор та систематичних вправ (Пискунов, 2019, с. 256). Фрідріх Фребель приймав за основу виховання «внутрішній закон», як вираження божої активності, тому важливу роль відводилося фізичній роботі, праці.

Ідеї німецького філософа, психолога і педагога Йогана Фрідріха Гербарта про те, що світ складається з незмінних найпростіших сутностей, які вступають у різні взаємозв'язки, створюючи лише враження, що світ змінюється, сприяли розробці системи гуманного виховання, що базувалася на п'яти моральних цінностях: 1) внутрішня свобода, що робить людину вільною; 2) досконалість, що вміщує в собі силу й енергію волі і дає «внутрішню гармонію»; 3) прихильність, яка полягає в узгодженні волі однієї людини з волею інших людей; 4) право людини, що застосовується у разі конфлікту двох чи кількох воль; 5) справедливість, яка визначає нагороду тому, хто служить суспільству, або покарання того, хто порушує закон (Ільченко, 2006). В основу 
духовного життя Йоган Фрідріх Гербарт поклав самосвідомість, з якої виводив і почуття, і волю, і всю поведінку людини. Він вважав, що особистістю керує коло уявлень, що включає в себе комплекс знань, ідей, які сприймає дитина. Тому завдання педагога - підібрати і дати знання, які б сприяли повноцінному вихованню особистості (Корнетов, 1993).

Послідовницею цих відомих філософів, педагогів стала Марія Монтессорі - перша в Італії жінка-лікар, філософ, педагог-гуманіст і психолог, яка розробила власну педагогічну систему, що є відомою й понині в різних країнах світу. Однак, на відміну від попередників, у своїх філософських поглядах М. Монтессорі наголошувала на тому, що для розуміння того, як дитина саморозвивається і самобудується, треба враховувати певний «внутрішній зародок», який є у неї до народження. Поступово людина реалізує ту програму, яка закладена в зародку природою. На думку педагога, людина формує всі аспекти своєї особистості через власний досвід взаємодії з навколишнім середовищем, сама створює себе. При створенні власної технології навчання М. Монтессорі спиралася на теорію вільного виховання, розвивального навчання, враховуючи те, що здібності дитини розвиваються відповідно до законів природи, розуміючи, що дитина засвоює краще ті знання, які грунтуються на чуттєвому досвіді, відповідають їі вікові та розвитку, є цікавими та поєднуються із практичним досвідом (Монтессори, 1997).

Вивчаючи та аналізуючи роботу М. Монтессорі «Космічне виховання» та іiі роздуми про місце людини в утворенні оточуючого, можемо зробити висновок, що, філософські погляди педагога базуються на «Космічній теорії», ідеї якої знайшли своє відображення у розумінні природи дитини і законів їі розвитку й викладені в книгах «Креативна дитина» та «Діти - інші». На думку М. Монтессорі, все в світі - рослини, тварини, людина - існує і діє у відповідності до космічного плану розвитку Всесвіту. Відомо, що все в природі пов’язано між собою, впливає одне на одного та доповнює одне одного. Отже, все, що існує у Всесвіті, розвивається, взаємодоповнює, тобто живе, і на все це може вплинути людина. Дитину слід виховувати так, щоб вона в майбутньому змогла змінити світ на краще (Montessori, 1993, с. 46).

Важливого значення М. Монтессорі надавала ролі людини в житті. Вона стверджувала, що життя - це горда богиня, яка постійно рухається вперед, долаючи перешкоди, що середовище ставить на ii переможному шляху. Філософ-освітянка винайшла основну істину: чи мова йде про вид, чи про індивід, істинний розвиток завжди забезпечено за тими переможними організмами, в яких є міцна й дійова таємна сила життя. Як слушно зауважувала М. Монтессорі, основна мета життя - вплинути на оточуюче середовище та досягти в ньому 
визначеної мети, оскільки життя проявляється, життя творить, життя дає і в свою чергу тримається у відомих межах і пов'язане відомими законами, яких не переступиш (Montessori, 1993, с. 68).

Педагог-просвітителька розрізнила дві форми життя: життя дорослого та життя дитини та показала їх взаємозв’ язок. Сучасні науковці, аналізуючи погляди М. Монтессорі на життя дорослої людини й дитини, пояснюють їх різницю: 1) різниця в рівні розвитку дитини і дорослого; 2) різниця в характері їхньої роботи; 3) особливості розумового розвитку, властиві дитині (Сорокова, 2003).

Різниця у рівні розвитку дорослого і дитини визначається тим, що дорослий - це людина, яка вже склалася, як психічно так і фізично, а дитина - ні. Різниця в характері роботи дорослої людини та дитини полягає в іiі діяльності. Доросла людина змінює оточуючий світ 3 метою пристосування його до власних потреб. Дитина діє іноді безсвідомо, ïi робота є проявом природної потреби розвитку, і мета їі полягає у розвитку різноманітних функцій і побудови власного життя. В той час як для дорослих робота зазвичай є обтяжуючим обов'язком, дитині притаманне таке ставлення до життя, за якого праця, виконання власного обов'язку приносять радість і щастя (Montessori, 1992, с. 75).

Виникає питання «Що таке дитяче життя?». Відповідь знаходимо у працях М. Монтессорі, яка зауважує, що дитяче життя - не абстракція, це - життя окремих дітей. Тобто кожна дитина має власний розвиток, свої можливості, це індивідуальність, якій потрібно допомагати і спрямовувати. Педагог-філософ пояснювала, що дитяче життя - це «інший полюс людської природи» (Montessori, 1994, с. 208). Доросла людина повинна оцінити дитину, яка впливає на цей світ, проникнути почуттям глибокого «благоговіння» до життя; спостерігаючи за дитиною з гуманним інтересом, поважаючи розвиток у дитині цього життя - навчити керувати, використовувати і створювати середовище, в якому розвивається дитина. «Дитина є тіло, яке росте, i душа, яка розвивається, - у цих двох формах, фізіологічній і психічній, одне i теж вічне джерело - саме життя. Ми повинні ні придушувати, ні спотворювати таємні сили, закладені у цих двох формах росту; ми повинні дочекатися від них проявів, які ми знаємо, підуть одне за одним» (Montessori, 1992, с. 105). В той же час дорослий відповідає за життя дитини, за розвиток особистості, створюючи умови для вільної діяльності дитини, які б відповідали потребам внутрішнього життя. I головне, зазначала педагог, це вірити в дитину, в їі можливості, в те, що вона здатна обновити людство .

Аналізуючи філософські ідеї педагогічної системи М. Монтессорі щодо розвитку дитини, ïi життя та місця у цьому світі можна ви- 
значити основні філософські принципи педагога-філософа: принцип єдності людини з природою; принцип постійного розвитку Всесвіту та пріоритет у цьому процесі людини; принцип диференціації ролей дорослого і дитини у житті; принцип гуманного ставлення до дитини; принцип віри у потенціал дитини, що реалізується у майбутньому; принцип застосування дисципліни для розвитку свободи дитини (Ільченко, 2006).

Відомий філософ-освітянин і соціолог ХХ ст. Карл Поппер доводив, що педагог не повинен нав' язувати своє мірило «вищих» учням, а мусить збуджувати їхній інтерес до цих цінностей. Він повинен піклуватися про душі своїх учнів. Тому вчителю, якому громада довірила формування активних цілеспрямованих особистостей, необхідно обирати за мету принципи співпраці, діалогу, толерантності. Дитина повинна відчувати потребу стати незалежною від дорослого й спроможною робити власний вибір. Дорослий, у свою чергу, повинен допомагати ій у цьому, направляти іiі можливості в потрібне русло, створювати освітнє середовище, яке б сприяло всебічному розвитку особистості (Поппер, 1994).

Висновки. Аналіз історичної і сучасної наукової літератури показав, що проблемою ролі й значення людини в житті, питаннями формування гармонійно розвиненої особистості цікавилися чимало відомих філософів, просвітителів, педагогів в різні історичні часи. Їх філософсько-педагогічні ідеї щодо забезпечення сприятливих умов для всебічного розвитку вільної особистості на основі гуманістичних ідеалів дають можливість сформулювати основні пріоритети сучасної освіти: гуманізація та демократизація. Гуманістична парадигма сучасної освіти полягає в утвердженні особистості кожної дитини як найвищої соціальної цінності, в розкритті її здібностей, задоволенні різноманітних освітніх потреб, забезпечення пріоритетності загальнолюдських і громадянських цінностей, гармонії стосунків дитини з оточуючим середовищем та іншими людьми.

Перспективи подальших досліджень вбачаємо у реалізації гуманістичних ідей в освітній процес сучасних закладів освіти.

\section{Список використаних джерел}

Вершинина Е. М. Непрерывное воспитание и гуманизация в системе образования - суть социально-экономического и духовного возрождения общества : Концепция. Харків : Регион-информ, 2004. 430 с.

Джуринский А. Н. Зарубежная школа : история и современность : учеб. пособ. Москва : Изд. Российского открытого ун-та, 1992. 177 с. 
Ільченко А. М. Філософські аспекти гуманістичної педагогіки Марії Монтессорі. Дидактичні та соичіально-психологічні аспекти корекційної роботи у спеціальній школі : наук.-метод. зб. / за ред. В. І. Бондаря, В. В. Засенка. Київ : Наук. світ, 2006. Вип. 7. С. 27-30.

История педагогики и образования : учебник для среднего профессионального образования / под ред. А. И. Пискунова. 4-е изд., перераб. и доп. Москва : Юрайт, 2019. 452 с.

Корнетов Г. Б. Гуманистическое образование : традиции и перспективы. Москва : ИТП и МИО РАО, 1993. 135 с.

Локк Дж. Сочинения : в 3 т. Москва : Мысль, 1988. Т. 3. 668 с.

Монтессори М. Разум ребенка (главы из книги). Москва : Крааль, 1997. 176 с.

Песталоцци И. Г. Избранные педагогические сочинения : в 2 т. Москва : Педагогика, 1981. Т. 1. 333 с.

Поздняков А. Н. История педагогики и образования за рубежом и в России : учеб. пособ. Саратов : Изд. центр «Наука», 2009. 143 с.

Поппер К. Відкрите суспільство та його вороги. Київ : Основа, 1994. Т. 1. 444 c.

Pycco Ж.-Ж. Pro et Contra. Идеи Жан-Жака Руссо в восприятии и оценке русских мыслителей и исследователей (1752-1917). Антология. СанктПетербург : Изд-во РХГА, 2005. 798 с.

Сорокова М. Г. Система М. Монтессори: Теория и практика : учеб. пособ. для студ. высш. пед. учеб. заведений. Москва : Академия, 2003. 384 с.

Філософський енциклопедичний словник / В. І. Шинкарук, Л. В. Озадовська, Н. П. Поліщук, І. О. Покаржевська. Київ : Абрис, 2002. 742 с.

Montessori M. Das kreative Kind. Freiburg; Basel; Wien, 1992.

Montessori M. Kinder sind anders. Munchen, 1994.

Montessori M. Komische Erziehung. Freiburg; Basel; Wien, 1993.

\section{References}

Dzhurinskij, A. N. (1992). Zarubezhnaja shkola : istorija i sovremennost' [Foreign school : history and modernity]. Moskva: Izd. Rossijskogo otkrytogo un-ta [in Russian].

Ilchenko, A. (2006). M. Filosofski aspekty humanistychnoi pedahohiky Marii Montessori [Philosophical aspects of humanistic pedagogy of Maria Montessori]. In Dydaktychni ta sotsialno-psykholohichni aspekty korektsiinoi roboty u spetsialnii shkoli [Didactic and socio-psychological aspects of correctional work in a special school] (Vol. 7, pp. 27-30). Kyiv: Nauk. svit [in Ukrainian].

Kornetov, G. B. (1993). Gumanisticheskoe obrazovanie : tradicii i perspektivy [Humanistic education: traditions and perspectives]. Moskva: ITP i MIO RAO [in Russian].

Lokk, Dzh. (1988). Sochinenija : v 3 t. [Works: in 3 volumes] (Vol. 3). Moskva: Mysl' [in Russian].

Montessori, M. (1992). Das kreative Kind. Freiburg; Basel; Wien.

Montessori, M. (1994). Kinder sind anders. Munchen.

Montessori, M. (1993). Komische Erziehung. Freiburg; Basel; Wien. 
Montessori, M. (1997). Razum rebenka (glavy iz knigi) [The mind of a child (chapters from the book)]. Moskva: Kraal' [in Russian].

Pestalocci, I. G. (1981). Izbrannye pedagogicheskie sochinenija : v 2 t. [Selected pedagogical works: in 2 volumes.] (Vol. 1). Moskva: Pedagogika [in Russian].

Piskunov, A. I. (Ed.). (2019). Istorija pedagogiki i obrazovanija [History of pedagogy and education] (4nd ed.). Moskva: Jurajt [in Russian].

Popper, K. (1994). Vidkryte suspilstvo ta yoho vorohy [Open society and its enemies] (Vol. 1). Kyiv: Osnova [in Ukrainian].

Pozdnjakov, A. N. (2009). Istorija pedagogiki $i$ obrazovanija za rubezhom $i v$ Rossii [History of pedagogy and education abroad and in Russia]. Saratov: Izdatel'skij centr "Nauka" [in Russian].

Russo, Zh.-Zh. (2005). Pro et Contra. Idei Zhan-Zhaka Russo v vosprijatii i ocenke russkih myslitelej i issledovatelej (1752-1917). Antologija [Pro et Contra. The ideas of Jean-Jacques Rousseau in the perception and assessment of Russian thinkers and researchers (1752-1917). Anthology]. Sankt-Peterburg: Izd-vo RHGA [in Russian].

Shynkaruk, V. I., Ozadovska, L. V., Polishchuk, N. P. \& Pokarzhevska, I. O. (2002). Filosofskyi entsyklopedychnyi slovnyk [Philosophical encyclopedic dictionary]. Kyiv: Abrys [in Ukrainian].

Sorokova, M. G. (2003). Sistema M. Montessori: Teorija i praktika [M. Montessori System: Theory and Practice]. Moskva: Akademija [in Russian].

Vershinina, E. M. (2004). Nepreryvnoe vospitanie $i$ gumanizacija $v$ sisteme obrazovanija - sut' social'no-jekonomicheskogo $i$ duhovnogo vozrozhdenija obshhestva [Continuous upbringing and humanization in the education system is the essence of the socio-economic and spiritual revival of society]. Harkiv: Region-inform [in Russian].

\section{Ilchenko A. M.}

\section{PHILOSOPHICAL PRINCIPLES OF ESTABLISHMENT AND DEVELOPMENT OF THE HUMANISTIC PARADIGM OF EDUCATION}

In the research, the philosophical principles of the formation and development of humanistic pedagogy are defined. Based on analysis of scientific literature, content of the concept of "humanism" are describes. Humanism is a system of ideas and views on man as the greatest social value, creating conditions for his full life and physical and spiritual development.

Humanitarian paradigm in education is based on the position of boundless faith in the nature of children, its value in this world, orientation to the ideal of a free, independent, active personality. At the heart of the humanization of education are phenomena: ethical norms, social ideal, spiritual value, freedom, mutual assistance and cooperation, respect for human rights and dignity, equality and equality, justice, protection from evil and violence, and more. 
Ideas on the nature and development of the child's personality of famous educators, philosophers: John Locke, Jean-Jacques Rousseau, Johann Friedrich Herbart, Johann Heinrich Pestalozzi, Friedrich Froebel and Maria Montessori are described in the article. The teacher must form active purposeful individuals, choose in teaching the principles of cooperation, dialogue, tolerance. The children must feel the ëneed to become independent of the adult and learn to make their own choices. Philosophical ideas of these foreign philosophers and teachers have an impact on the development of modern education.

Key words: humanism, humanitarian paradigm, education, personality, education philosophy, teacher. 